\title{
Beryllium Materials for National Ignition Facility Targets LDRD Final Report
}

\author{
R. L. McEachern
}

February 27, 2001

U.S. Department of Energy

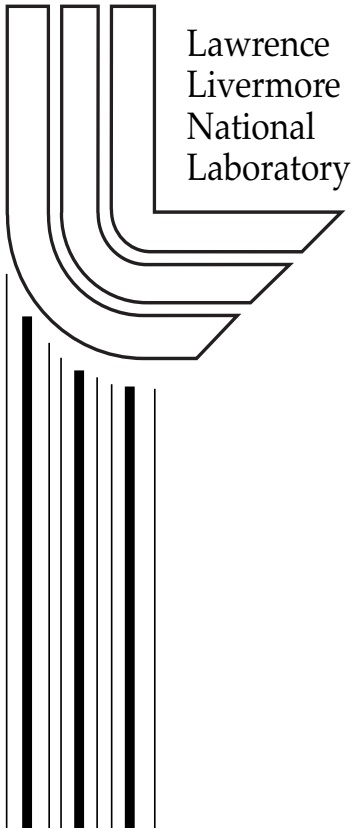




\section{DISCLAIMER}

This document was prepared as an account of work sponsored by an agency of the United States Government. Neither the United States Government nor the University of California nor any of their employees, makes any warranty, express or implied, or assumes any legal liability or responsibility for the accuracy, completeness, or usefulness of any information, apparatus, product, or process disclosed, or represents that its use would not infringe privately owned rights. Reference herein to any specific commercial product, process, or service by trade name, trademark, manufacturer, or otherwise, does not necessarily constitute or imply its endorsement, recommendation, or favoring by the United States Government or the University of California. The views and opinions of authors expressed herein do not necessarily state or reflect those of the United States Government or the University of California, and shall not be used for advertising or product endorsement purposes.

This work was performed under the auspices of the U. S. Department of Energy by the University of California, Lawrence Livermore National Laboratory under Contract No. W-7405-Eng-48.

This report has been reproduced directly from the best available copy.

Available electronically at http://www.doc.gov/bridge

Available for a processing fee to U.S. Department of Energy

And its contractors in paper from

U.S. Department of Energy

Office of Scientific and Technical Information

P.O. Box 62

Oak Ridge, TN 37831-0062

Telephone: (865) 576-8401

Facsimile: (865) 576-5728

E-mail: reports@adonis.osti.gov

Available for the sale to the public from

U.S. Department of Commerce

National Technical Information Service

5285 Port Royal Road

Springfield, VA 22161

Telephone: (800) 553-6847

Facsimile: (703) 605-6900

E-mail: orders@ntis.fedworld.gov

Online ordering: http://www.ntis.gov/ordering.htm

OR

Lawrence Livermore National Laboratory

Technical Information Department's Digital Library

http:/ / www.llnl.gov/tid/Library.html 


\title{
Beryllium Materials for National Ignition Facility Targets LDRD Final Report
}

\author{
99-ERD-002
}

Principal Investigator: Randall L. McEachern

The National Ignition Facility (NIF) will require spherical ignition capsules approximately $2 \mathrm{~mm}$ in diameter with a 120 - to $150-\mu \mathrm{m}$-thick ablator. Beryllium-based alloys are promising candidates for an ablator material due to their combination of low opacity and relatively high density (compared to polymer coatings). For optimum performance, the Be-coated capsules require a smooth surface finish, uniform thickness, microscopic homogeneity, and preferably high strength. The coatings must contain on the order of 1 at.\% of a high- $\mathrm{Z}$ dopant (such as $\mathrm{Cu}$ ) and permit the capsule to be filled with fuel, which will be a mixture of hydrogen isotopes. These demanding requirements can be met through a synthesis method with a focus on the control of microstructure. In our experiments, the sputter deposition process has been manipulated so as to decrease the grain size, thereby reducing roughness and improving homogeneity.

The material properties of sputter-deposited coatings are sensitive to their microstructure and growth morphology. To meet the requirements for Be coated capsules, the goal of this project was to optimize the microstructure and growth morphology through the control of deposition process parameters.

Prior experimental studies of evaporation and sputter deposition revealed that the grain size of 99.8 at.\% pure Be can be reduced by adding insoluble metal impurities such as Fe or Ti. These higher atomic weight elements can replace the requirement of adding 1 at.\% $\mathrm{Cu}$ to the Be. Grain size can also be reduced by using additives that are metallic-glass formers, such as boron. Finally, the microstructure can be modified by changing the energy or angular distribution of the depositing flux.

Our initial experiments focused on the development of Be-B- $X$ alloys, where $\mathrm{X}$ is $\mathrm{Fe}$ and/or $\mathrm{Cu}$. This work was successful in reducing the grain size of coatings deposited on planar substrates from microns to at least nanometers. TEM cross sections of these films showed no discernible grain structure, so for the purposes of this project the material was a glass. Deposition of a few $\mu \mathrm{m}$ of this alloy onto stationary capsules produced extremely smooth films: rms roughnesses of about $1 \mathrm{~nm}$ were observed using atomic force microscopy. As the coating thickness was increased, however, intrinsic stress in the film became a serious problem. Buckling and delamination were the typical symptoms of this phenomenon. Although there are techniques for mitigating stress build-up in deposited films, we concluded it would pose a formidable problem for the very thick coatings required for NIF capsules. For this reason, we shifted our efforts away from glassy alloys and concentrated on modifying the energy and angular distribution of the depositing $\mathrm{Cu}$-doped beryllium flux.

Application of a negative substrate bias draws positive ions from the ambient sputter gas, inducing bombardment of the growing film. The ionassisted deposition process results in dense columnar growth and reduced grain size. The effect on mechanical strength is also favorable: introduction of ion bombardment increases the fracture stress of $\mathrm{Cu}$-doped Be capsules from less 
than $40 \mathrm{MPa}$ to greater than $200 \mathrm{MPa}$. The roughness of $10-\mu \mathrm{m}$-thick coatings has been reduced from $\sim 150 \mathrm{~nm}$ to $\sim 30 \mathrm{~nm} \mathrm{rms}$. In support of these experiments, we developed a technique for producing a variable-intensity glow discharge above the substrate. This provides a means for adjusting the bombardment current at a fixed energy. We have routinely obtained films on planar substrates with roughly $10 \mathrm{~nm} \mathrm{rms}$ surfaces. The other process modification we studied was to restrict the angular distribution of the depositing atoms. When atoms land on a growing film from all directions (isotropic deposition), surface roughness tends to be amplified by the process of self-shadowing. By using an aperture to restrict the flux to near-normal incidence, coatings were produced with a grain size of roughly $60 \mathrm{~nm}$ and a roughness of $5 \mathrm{~nm} \mathrm{rms}$. These results were encouraging, but they mostly served as a proof of prinicple. The technique suffers from an extremely slow deposition rate: to produce a NIF-thickness capsule would require many weeks of coating.

Although this LDRD ended before detailed studies of bias-deposited capsules could be completed, our results point to this as a promising approach to producing fine-grained, smooth $\mathrm{Cu}$-doped beryllium capsules. Not only can the capsules be mass produced, but other dopants can be incorporated in place of copper with relatively minor modifications.

This work was performed under the auspices of the U.S. Department of Energy by the University of California, Lawrence Livermore National Laboratory under Contract No. W-7405-Eng-48. 